\title{
Pengembangan Desa Pertanian Cabai Desa Bongki Lengkese Sinjai Timur Kabupaten Sinjai
}

\author{
Riskasari \\ Program Studi Ilmu Administrasi Negara Fisip Unismuh Makassar \\ Email: rikasari@unismuh.ac.id
}

\begin{abstract}
Abstraksi
Tujuan dari penelitian ini untuk mengetahui pengembangan desa petani cabai melalui beberapa inovasi dengan memperhatikan faktor pendukung dan faktor penghambat produksi cabai di Desa Bongki Lengkese Kecamatan Sinjai Timur Kabupaten Sinjai. Tipe penelitian ini menggunakan pendekatan studi kasus. Adapun jumlah informan sebanyak enam orang. Teknik pengumpulan data dengan wawancara, observasi, penelitian kepustakaan, dokumentasi. Hasil penelitian ini menunjukkan bahwa keputusan untuk melakukan inovasi petani cabai di Desa Bongki Lengkese Kecamatan Sinjai Timur Kabupaten Sinjai dipengaruhi oleh beberapa faktor antara lain adalah, kreativitas, keahlian, kemampuan berpikir, motivasi internal dan kemampuan melakukan penghitungan resiko serta memiliki faktor pendukung berupa kerjasama dengan perusahaan PT Hextar Seed dan Dinas Pertanian, untuk pengadaan bibit dengan kualitas unggul dan harga terjangkau. Adapun faktor penghambat dari produksi cabai adalah keterbatasan alat dalam proses pemeliharaan sampai pada proses panennya dan lokasi pemasaran yang tidak tetap serta harga jual cabai yang tidak stabil.
\end{abstract}

Kata Kunci: Inovasi, faktor pendukung, faktor penghambat.

\begin{abstract}
The purpose of this research was to determine innovation in production development as well as supporting factors and inhibiting factors for chili production in Bongki Lengkese Village, East Sinjai District, Sinjai Regency. The type of this research used case study approach. The number of informants was 6 persons. The technique of collecting data were by interviews, observation, library research, documentation. The results of this study indicate that the decision to innovate chili farmers in Bongki Lengkese Village, East Sinjai District, Sinjai Regency is influenced by several factors, such as creativity, expertise, thinking ability, internal motivation and the ability to calculate risk also have supporting factors in the form of cooperation with companies PT Hextar Seed and the Department of Agriculture, for the procurement of seeds with superior quality and affordable prices.The inhibiting factors of chili plantations are the limited tools in the maintenance process up to the harvesting process, the unstable marketing location and the unstable selling price of chilies.
\end{abstract}

Keywords: innovation, supporting factors, inhibiting factors.

\section{Pendahuluan.}

Pembangunan ekonomi di Indonesia, mempunyai peranan penting yang sangat bermanfaat bagi kehidupan setiap penduduk karena bertujuan untuk menghasilkan dan mengembangkan perekonomian mereka terutama dalam bidang perkebunan. Undang-undang Republik Indonesia Nomor 39 Tahun 2014 tentang perkebunan "Bahwa perkebunan berperan penting dan memiliki potensi besar dalam pembangunan perekonomian nasional dalam 
rangka mewujudkan kemakmuran dan kesejahteraan rakyat secara berkeadilan". Hal ini merupakan tujuan penting untuk diterapkan dalam pembangunan perkebunan agar tingkat perekonomian semakin berkembang.

Melonjaknya para pedagang perkebunan cabai di Indonesia dalam persaingan pasar semakin signifikan karena mengakibatkan sejumlah pedagang mengalami persaingan yang begitu ketat. Sehingga, banyak dari sekian pedagang menentukan lebih awal target pemasarannya sudah ditentukan agar supaya persaingan pasar dalam memasarkan bisa teratasi dengan baik. Khususnya yang berada di Desa Bongki Lengkese Kecamatan Sijai Timur Kabupaten Sinjai yang merupakan salah satu propinsi yang dikenal sebagai sektor pertanian dalam menghasilkan sayuran-sayuran misalkan tanaman cabai. Cabai merupakan salah satu jenis sayuran yang memiliki nilai manfaat bagi setiap pengolahan makanan yang berbahan baku cabain.

Menurut Nasution \& Kartjaya (2018) dalam bukunya yang berjudul "Inovasi”, Inovasi menjadi kalimat sakral dalam kemajuan dan kesejahteraan suatu bangsa, baik di level mikro ekonomi (korporasi) hingga level makro ekonomi (Negara). Di level korporasi, jargon "inovasi atau mati" selalu didengungkan untuk menginspirasipara karyawan dan professional untuk berkreasi serta menghasilkan "nilai tambah" ekonomis, baik dari sisi produk/jasa, proses, hingga system manajemen. Bila penemuan (invention) bisa dimaknai sebagai penciptaan konsep atau teknologi baru yang terjadi secara kebetulan atau "trial error" dengan tujuan memenuhi suatu perbaikan berkelanjutan, maka inovasi memiliki beragam definisi tergantung dari sudut pandang bidang kajian. Briessen dan De Ende (Nasution \& Kartjaya ; 2018) sebuah konsep inovasi merupakan kerangka yang relevan untuk semua jenis bisnis, terlepas dari sektor dan skala bisnisnya dalam konteks ini telah di kembangkan suatu model inovasi yang komprehensif serta terpadu.

Menurut Muchlas (2015) inovasi merupakan strategi dinamis (terhadap lingkungan bisnis) yang harus diterapkan oleh manajemen agar mampu bersaing dan memiliki kinerja tinggi. Inovasi dapat dilakukan dengan berbagai tingkatan, antara lain pada level produk (ornamen, warna, kemasan, bentuk, dll), proses (penambahan bahan, efisiensi teknologi produksi, produksi, dll), dan pada level manajemen (pelayanan konsumen, strategi pemasaran, strategi kerjasama, dll). Inovasi itu sendiri merupakan sebuah informasi bagi organisasi untuk menghasilkan hal-hal baru untuk sebuah program yang dijalankan baik itu dalam bidang ekonomi ataupun dalam bidang lainnya. Kuratko (2005), dengan demikian wajar jika menajemen inovasi telah menjadi fokus utama dari penelitian akademik maupun industry secara intensif, dalam rangka mengatasi berbagai problematika bisnis yang sedang dihadapi oleh perusahaan untuk mencapai sebuah keunggulan kompetitif yang berkelanjutan dalam persaingan global. Manajemen inovasi sebuah ide yang dikelola secara maksimal untuk membantu meningkatkan daya saing pasar yang ada di setiap perusahaan itu. Manajemen inovasi sebuah ide yang dikelola secara maksimal untuk membantu meningkatkan daya saing pasar yang ada di setiap perusahaan itu.

Areal panen yang cukup luas ditunjang dengan penanaman cabai serentak satu desa, menunjang peningkatan hasil produksi mencapai 40 ton/ tahun. Menggunakan strategi baru 
dalam meningkatkan pengembangan produksi adalah cara yang paling efektif karena bertujuan untuk menghasilkan panen berkualitas. Sehingga dalam hal ini dikemukakan oleh Bapak Manajemen Dunia Peter Drucker (2005) dalam upaya untuk menciptakan perubahan yang bertujuan dan fokus dalam suatu potensi ekonomi atau sosial.

Inovasi dalam pengembangan cabai memerlukan sebuah ide baru atau rancangan produksi cabai yang lebih baik dari sebelumnya serta pencapaian suatu tujuan diperlukan perubahan baru untuk melihat seperti apa hasil dari pencapaian suatu perkembangan penanaman cabai khususnya di Desa Bongki Lengkese Kecamatan Sinjai Timur Kabupaten Sinjai. Maka dari itu diperlukan suatu gagasan baru sehingga mengaitkan dimensi-dimensi dalam inovasi itu sendiri. Berdasarkan pendapat dari Nasution \& Kartajaya (2018) dalam bukunya yang berjudul "Inovasi" menetapkan 2 (dua) dimensi yang mendasari pengelolaan inovasi yatitu: (1) Kreativitas, dan (2) Pengambilan resiko, yang mendorong kearah pencapaian kinerja yang lebih efisien dan efektif.

Permasalahan yang terjadi dalam pengembangan perkebunan cabai disebabkan hasil produksi yang cukup bersaing secara kualitas dan cukup unggul secara kuantitas dengan produksi rata-rata 40 ton/ tahun sejak 2017 hingga 2020. Bahkan pernah mencapai 120 ton pada tahun 2018 dengan adanya penanaman cabai serentak oleh masyarakat di Desa Bongki Lengkese Kecamatan Sinjai Timur Kabupaten Sinjai. Namun produksi yang melimpah tidak didukung dengan wadah pemasaran yang tetap sehingga harga relatif tidak stabil. Disampaikan oleh MR selaku Ketua Kelompok tani Cabe Desa Bongki Lengkese bahwa jika harga normal terjual sekitar dua puluh lima ribu rupiah (Rp.25.000/Kg) maka penghasilan dapat mencapai delapan ratus juta ( $R p$ 800.000.000/ tahun). Oleh sebab itu, para petani mengharapkan dari Pemerintah Kabupaten Sinjai untuk membantu terkaitpersoalan wadah pemasaran produksi agar tanaman cabai bisa dijual dengan harga normal atau stabil serta sukses dipasarkan agar tidak merugikan masyarakat terutama para petani cabai seperti yang terjadi pada tahun 2020, dimana harga cabai turun drastis mencapai angka dua ribu rupiah (Rp.2000/Kg). Sehingga, hasil penjualan tidak sebanding dengan jumlah produksi dan biaya pemeliharaan yang dikeluarkan oleh para petani cabai.

Berdasarkan pendapat dari Nasution \& Kartjaya (2018) dalam bukunya yang berjudul "Inovasi"menetapkan dua dimensi yang mendasari pengelolaan inovasi, yaitu: (1) kreativitas, kemampuan untuk mengembangkan ide baru yang terdiri dari berbagai aspek seperti keahlian, kemampuan berpikir fleksibel, imajinatif, dan juga motivasi internal; (2) pengambilan risiko, kemampuan untuk mendorong ide baru, memilih strategi denga resiko terukur, menghadapi rintangan yang ada sehingga pengambilan risiko merupakan cara mewujudkan ide yang kreatif menjadi realistis.

Pengelolaan Tanaman Terpadu (PTT) merupakan suatu strategi atau model pengelolaan tanaman untuk meningkatkan produksi tanaman melalui integritas teknologi yang memiliki efek sinergis. PTT pada prinsipnya adalah suatu upaya mengoptimalkan bagi setiap penggunaan sumber daya dan memanfaatkan teknologi pertanian. Pengendalian hama terpadu (PHT) pada tanaman cabai merah yang diadaptasi dari hasil penelitian Soedarwohadi S., dkk (Rahmat \& Herdi, 2017) adalah melakukan berbagai teknik pengendalian hama. Secara 
terinci taktik PHT cabai. Pemeliharaan cabai sangat diperlukan dalam pengelolaan agar bisa menghasilkan cabai-cabai berkualitas dan pertumbuhannya juga semakin optimal sehingga bisa menunjang hasil panen yang lebih baik. Seperti yang dikemukakan oleh (Syukur, 2018) memberikan 5 langkah pemerliharaan cabai agar tumbuh secara optimal. Sebagai berikut; Pengairan, Penyulaman, Perempelan, Pengajiran, dan Pemupukan susulan.

Buah cabai merupakan tanaman sayuran yang bisa meningkatkan nilai ekonomis yang tinggi bagi pedagang serta dapat dimanfaatkan sebagai bahan masakan atau bumbu dapur dan bukan hanya itu tanaman cabai juga bisa digunakan sebagai bahan pengobatan tradisional. Buah cabai bermanfaat untuk membantu pencernaan tubuh manusia sehingga tidak heran jika manusia mengomsumsi makanan yang bercampur dengan cabai, pencernaannya menjadi terganggu atau perutnya terasa mules bukan karena gangguan yang fatal tetapi untuk membantu melencarkan pencernaan yang tadinya susah buang air besar menjadi lencar buang air besar.

Pencapaian output yang maksimum dengan input tertentu atau bagaimana kita bisa menggunakan input terendah untuk mencapai output tertinggi (yang diinginkan). Efesiensi merupakan suatu perbandingan output atau input yang dapat dikaitkan dengan standar kinerja atau target yang telah ditentukan. Deddy dan Ayuningtyas (Nasution \& Kartjaya, 2018) mengemukakan bahwa organisasi sektor tertentu dinilai semakin efisien apabila rasio efesiensi cenderung diatas satu. Semakin besar rasio, maka semakin tinggi tingkat efesiensinya. Sebagai satuan kinerja, efesiensi harus dibandingkan dengan angka acuan tertentu, seperti efesiensi periode sebelumnya (inward looking bases) atau efesiensi di organisasi benchmark sektor tertentu lainnya yang menantang (outward looking bases).

Tingkat pencapaian hasil (pelaksanaan program) dengan target yang ditetapkan. Secara sederhana efektifitas merupakan perbandingan outcome (hasil akhir yang ingin dicapai) dengan output (aktivitas/program yang dijalankan agar outcome tercapai). Semakin besar konstribusi output terhadap outcome, mengindikasikan semakin efektif struktur organisasi dan tepat sasaran program atau kegiatan yang dirancang dan diimplementasikan. Jika efesiensi berfokus pada output dan proses, maka efektivitas berfokus pada outcome (hasil).

Seperti yang dikemukakan Widyaningdyah dan Aryani (Nasution \&Kartjaya, 2018) suatu perusahaan dikatakan mempunyai keunggulan kompetitif, jika dapat menciptakan nilai ekonomis yang lebih tinggi dibandingkan dengan perusahaan lain dalam industrinya.

\section{Metode}

Tipe penelitian ini menggunakan pendekatan studi kasus karena meneliti fenomena yang terjadi dalam masyarakat terkait strategi inovasi oleh Petani cabai di Desa Bongki Lengkese. Sumber data dalam penelitian ini adalah data primer merupakan data yang diperoleh peneliti dengan melakukan wawancara terhadap informan dalam hal ini Kepala Desa bersama perangkat Desa Bongki Lengkese selaku informan kunci serta Kelompok Tani 
Cabai dan beberapa masyarakat di Desa Bongki Lengkese.Data Sekunder diperoleh dengan cara pengambil data dari buku, jurnal, artikel, serta aturan-aturan yang berkaitan dengan judul penelitian penulis.

Untuk memperoleh data, sumber data yang digunakan dalam penelitian ini adalah, Wawancara dilakukan langsung kepada Desa Bongki Lengkese dan melakukan tanya jawab kepada, kelompok tani dan masyarakat serta pihak-pihak terkait, Observasi Penelitian dengan pengamatan langsung tentang bagaimana pengelolaan perkebunan cabai oleh masyarakat yang berada di Desa Bongki Lengkese Kecamatan Sinjai Timur Kabupaten sinjai.

\section{Hasil dan Pembahasan}

Sesuai dengan tujuan penelitian yaitu ingin mengetahui Inovasi petani dalam mengembangkan produksi cabai di Desa Bongki Lengkese Kecamatan Sinjai Timur Kabupaten Sinjai, maka penulis melakukan metode penelitian kualitatif dengan narasumber yang berkaitan inovasi terhadap Perkebunan Cabai di wilayah tersebut dengan melakukan teknik wawancara terhadap informan yang terkait.

Hal yang perlu diketahui bahwa Inovasi Perkebunan Cabai merupakan ide yang dikeluarkan oleh pihak pemerintah ataupun dari pihak pengelola cabai tersebut untuk mengembangkan perkebunan cabai dengan menghasilkan buah yang berkualitas dengan kenaikan harga yang maksimal.

Inovasi merupakan hal yang penting dalam membangun adanya perkembangan untuk melihat sebuah kualitas ataupun perubahan khususnya dalam perkebunan cabai tersebut, maka dari itu penulis mengusulkan sebuah teori dari Nasution \& Kartajaya yang berkaitan dengan apa saja pengelolaan dalam inovasi karena penulis menganggap bahwa teori ini sangat cocok untuk mengetahui apa saja pengelolaan yang dilakukan untuk menciptakan inovasi dalam mengembangkan perkebunan cabai. Maka dari itu, teori ini sangat penting untuk menilai perkembangan dari Inovasi petani Cabai di Desa Bongki Lengkese Kecamatan Sinjai Timur Kabupaten Sinjai.Berikut adalah dimensi-dimensi dari Inovasi.

\section{Kreatifitas}

Kreatifitas yang dimaksud ialah kemampuan untuk membuat suatu perubahan yang baru dan memecahkan masalah serta membentuk sebuah ide kreatif dalam membangun perkebunan cabai yang dengan kualitas buah yang sangat baik. Kreatifitas dari perkebunan cabai Desa Bongki Lengkese memiliki beberapa ide kreatif dalam mengelola perkebunaan cabai demi meningkatkan produktivitas dari perkebunan dan bisa lebih meminimalisir pengeluaran biaya dalam mengelola perkebunan cabai. Maka hal itu sangat penting untuk mengoptimalkan upaya peningkatan produksi cabai. Kreatifitas dari perkebunan cabai merupakan proses untuk menjadikan sebuah perkebunan lebih baik dengan menghasilkan beberapa perubahan baru baik dari sistem pengelolaannya maupun dari kualitas buahnya. 


\section{Keahlian}

Keahlian yang dimaksud adalah kemampuan seseorang dalam mengolah tanah untuk pembuatan bedengan pada perkebunan cabai. Pengolahan tanah yang dilakukan dengan menggunakan beberapa alat elektronik untuk menunjang kelancaran pekerjaan dalam mengelola perkebunan cabai. Keahlian dalam kreatifitas inovasi memang hal itu sangat diperlukan untuk perkembangan dan perubahan baru untuk perkebunan cabai, hal itu dangat berperan penting untuk masa depan kemajuan tingkat kualitas dari perkebunan cabai, dan bukan tanaman cabai saja tetapi tanaman sayuran lainnya juga sangat diperlukan keahlian yang telah dikemukakan oleh beberapa anggota tani. Dilihat dari hasil wawancara salah satu tokoh masyarakat bahwa penanaman cabai untuk saat ini dengan pemakaian mulsa.

\section{Kemampuan Berpikir}

Kemampuan berpikir yang dimaksud ialah bagaimana pihak pemerintah ataupun pihak pengelolah perkebunan cabai bisa berpikir secara kreatif dengan memberikan ide untuk melihat perubahan baru dan perkembangan perkebunan cabai dengan kualitas cabai yang segar serta menghasilkan buah cabai yang lebih banyak. Kemampuan berpikir dalam kreatifitas memang sangat menunjang adanya perubahan baru perkebunan cabai yang berada di Desa Bongki Lengkese Kecamatan Sinjai Timur Kabupaten sinjai. Disebabkankan sebuah perubahan tidak akan bisa terjadi jika kemampuan berpikir dalam pengembangkan perkebunan cabai tidak dilakukan. kemampuan berpikir dalam kreatifitas inovasi memang hal itu sangat penting untuk menunjang keberhasilan perkebunan cabai agar bisa memiliki perubahan baik dari system pengelolaannya maupun dari kualitas buahnya.

Kemampuan berpikir untuk menciptakan sebuah inovasi perkebunan cabai cukup kreatif karena salah satu bahan yang harus digunakan seperti mulsa/plastik untuk menutup pori-pori tanah dan menjaga kesuburan tanah serta tangkai pohon cabai juga mereka gunakan untuk bisa menghasilkan buah cabai yang segar. Perkebunan cabai juga memerlukan perawatan yang rutin disaat kondisi iklim yang tidak kondusif. Imajinatif yang dimaksud ialah bagaimana pihak pengelola perkebunan cabai bisa berimajinasi atau memberikan ide/gambaran seperti apa perubahan baru dan perkembangan dari perkebunan cabai dimasa yang akan datang. Imajinatif sangat dibutuhkan untuk memberikan perkembangan yang sangat baik untuk perkebunan cabai karena bisa memunculkan beberapa ide kreatif untuk membuat buah cabai tidak hanya menghasilkan buah segar dan berkualitas tetapi bisa memiliki cakupan pemasaran yang sangat luas. imajinatif sangat diperlukan dan sangat penting untuk melihat perubahan baru dari sistem pengelolaan perkebunan cabai. Perkebunan cabai merupakan perkebunan dengan sistem pengelolaan yang banyak menggunakan alat serta biaya perawatan cukup besar maka hal itu sangat dianjurkan bagi pihak pemerintah memberikan bantuan berupa bibit atau alat demi menunjang perkembangan buah cabai di Desa Bongki Lengkese dan bisa memberikan ide atau gambaran dengan kreatif untuk menunjang pengembangan perkebunan cabai agar bisa menghasilkan buah cabai dengan kondisi yang sangat baik.

\section{Motivasi Internal}


Motivasi internal yang dimaksud ialah adanya dorongan untuk mengembangkan perkebunan cabai dari pihak pemerintah ataupun dari pihak pengelola. Motivasi internal sangat penting untuk diterapkan dalam perkebunan cabai maka dari itu, perlunya dorongan dengan bantuan bibit dan lokasi pemasaran tetap agar dapat mengontrol harga tetap stabil oleh pemerintah. Dengan adanya motivasi internal pengelolaan cabai bisa diperhatikan terutama dalam hal perawatan. Dibutuhkan beberapa tenaga kerja serta perhatian dari pemerintah setempat dengan memberikan alat teknologi dan biaya perawatan perkebunan cabai. Motivasi internal itu sendiri berpengaruh terhadap semangat para petani karena bisa mengakibatkan sistem pengelolaan tidak terjalankan secara maksimal dan bisa terjadi menurunnya semangat petani dalam mengelola cabai.

\section{Pengambilan Resiko Terukur}

Pengambilan resiko terukur merupakan hal yang sudah dipikirkan secara matang bahwa tindakan yang dilakukan memiliki resiko ke depannya maka dari itu merupakan salah satu hal penting karena berani menerima sebuah resiko atas tindakan yang dilakukan terutama dalam hal pengembangan perkebunan cabai. Banyak yang harus dipikirkan sebelum memutuskan untuk mengambil suatu tindakan dalam mengelola perkebunan cabai. pengambilan resiko terukur sangat diperhatikan dalam pengelolaan cabai karena masalah pengelolaan cabai bisa teratasi lebih awal karena sudah mengetahui tindakan yang diambil memiliki resiko baik untuk pengelolaan maupun dari sistem bantuan biaya. Maka hal itu sangat penting karena menunjang keberhasilan dalam mengembangkan perkebunan cabai di Desa Bongki Lengkese Kecamatan Sinjai Timur Kabupaten Sinjai.

Inovasi perkebunan cabai di Deasa Bongki Lengkese memerlukan upaya peningkatan dalam pengelolaan baik dari perawatannya maupun dari segi perhatian pemerintah daerah berupa bantuan bibit.Maka hal itu sangat menunjang keberhasilan inovasi perkebunan cabai dengan sistem pengelolaan yang baik. Faktor pendukung merupakan salah satu upaya peningkatan untuk menunjang keberhasilan atas inovasi perkebunan cabai di Desa Bongki Lengkese.Dalam hal ini, pengembangan dalam pengelolaan cabai sangat perlu perhatian dari masyarakat maupun pemerintah setempat. Peran penting dalam upaya peningkatan memerlukan faktor pendukung baik dari segi bibit, bahan maupun alat. Disamping itu,, dukungan untuk pengelolaan cabai di Desa Bongki Lengkese adalah bantuan dari pemerintah Kabupaten Sinjai, karena apapun yang menyangkut upaya peningkatan dalam hal pertanian, pemerintah memiliki peran penting.

Adanya program Inovasi Perkebunan Cabai di Desa Bongki Lengkese memiliki faktor pendukung berupa bantuan bibit dan alat pemeliharaan serta lahan yang memadai. Selain itu, faktor penghambat dalam inovasi perkebunan cabai berupa lokasi pemasaran yang tidak menentu serta harga jual yang tidak stabil.

Bantuan pemerintah setempat khususnya instansi yang terkait sangat dibutuhkan oleh petani cabai karena hal itu merupakan salah satu pendukung untuk peningkatan dalam pengelolaan cabai. Dalam hal ini sangat diperlukan perhatian dari berbagai pihak seperti instansi yang terkait yaitu Dinas Pertanian Kabupaten Sinjai dan penyuluhan pertanian serta 
adanya budidaya tanaman cabai sehingga program yang dijalankan lebih optimal dalam upaya peningkatan dan keberlanjutan produksi perkebunan cabai. Faktor pendukung dalam perkebunan cabai adalah hal yang penting untuk peningkatan cabai dari segi kualitas maupun kuantitas.

\section{Kesimpulan}

Inovasi perkebunan cabai merupakan ide untuk membuat sebuah perubahan untuk mengembangkan sebuah perkebunan, baik dari sistem pengelolaannya maupun dari sistem pemasarannya, sehingga dapat disimpulkan bahwa inovasi dari perkebunan cabai diDesa Bongki Lengkese Kecamatan Sinjai Timur adalah adanya penggunaan alat multifator guna untuk mengolah tanah dalam bentuk bedengan, serta pemakaian mulsa agar terhindar dari hama dan penyakit serta menjaga ketersediaan unsur hara untuk menunjang kualitas pertumbuhan cabai dapat meningkat secara kualitas dan kuantitas. (b) Faktor pendukung dari inovasi oleh petani cabai di Desa Bongki Lengkese Kecamatan Sinjai Timur Kabupaten Sinjai adalah adanya beberapa alat seperti multifator, pemakaian mulsa serta bibit yang unggul baik dari bantuan dinas pertanian maupun atas kerjasama dengan perusahaan PT Hextar Seed dengan kualitas unggul dan harga terjangkau. (c) Adapun Faktor penghambat berupa lokasi pemasaran yang tidak tetap serta harga jual cabai yang tidak stabil. Selain itu, keterbatasan alat dalam proses pemeliharaan sampai pada proses panennya karena tidak ada bantuan alat dari pihak terkait. (3) Kuantitas produksi cabai tidak selalu merujuk pada peningkatan hasil penjualan yaitu meskipun hasil produksinya mencapai 40 ton/tahun tetapi hasil penjualan tergantung pada harga pasar yang relatif tidak stabil.

Berdasarkan hasil penelitian yang dilakukan oleh penulis terkait dengan inovasi perkebunan cabai di Desa Bongki Lengkese Kecamatan Sinjai Timur Kabupaten Sinjai. Maka adapun saran yang dapat diberikan dalam penelitian ini adalah; (1) adanya bantuan berupa bibit, ataupun pupu dan sejenisnya selama proses untuk menunjang petani cabai dalam pemeliharaannya sampai proses panen. (2) Membutuhkan perhatian lebih dari pihak pemerintah terkait bantuan pemasaran hasil panen untuk menjaga stabilitas harga.

\section{Daftar Pustaka}

A, Hit Michael, dkk. 2001. “Manajemen Strategi”. Jakarta: Penerbit Salemba Empat.

A, Nasution H., \& Hermawan Kartajaya, 2018. "Inovasi”. Yogyakarta: Penerbit Andi.

David, Depari Hismanta, dkk. 2015. "Pengaruh Sistem Pengelolaan Usahatani Cabai Merah Terhadap Jumlah Produksi dan Tingkat pendapatan”. Jurnal Agribisnis. Diakses pada tanggal 28 Desember, pukul 21.15

Fred R, David. 2005. “Manajemen Strategis”. Jakarta: Penerbit Salemba Empat

H, Rukmana Rahmat, \& Yudirachman Herdi H. 2017. "Untung Selangit dari Agribisnis Cabai”. Yogyakarta: Lily Publisher. 
Haris, Perwiranegara Abdul. 2014. "Strategi Inovasi terhadap Kinerja UKM". Jurnal: Aplikasi Manajemen. Diakses pada tanggal 6 April, pukul 21.30.

Husein, Umar. 2005. "Strategic Management In Action". Jakarta: PT. Gramedia Pustaka Utama.

Irawaty. 2018. "Strategi pemasaran pendidikan vokasi di Indonesia". Jurnal Administrasi Negara. Diakses pada tanggal 4 April, pukul 14.56.

Iriani Endang, Mulanjari Eti M. 2018. "Pengembangan Produksi Cabai Merah Melalui Pendekatan Standar Operasional Prosedur Pada Musim Kemarau di Lahan Kering Kabupaten Blora”. Jurnal Teknologi Pertanian.Diakses pada tanggal 28 Desember, pukul 22.10.

LODM, Mustari, dkk. 2019. "Penyuluhan Laboratorium Lapangan Budidaya Terong dan Cabe Di Kelurahan Bandar Batauga Kecamatan Batauga Kabupaten Buton Selatan”. Jurnal Fakultas Pertanian. Diakses pada tanggal 30 Desember, pukul 21.30.

Lusiana. 2012. "Strategi Museum Perjuangan Kota Yogyakarta Dalam Menarik Minat Wisatawan”. Jurnal Administrasi. Diakses pada tanggal 25 April, pukul 22.15.

Muchlas, Zainal. 2015. "Strategi Inovasi dan Daya Saing”.

Muhammad, Syukur. 2018. "8 Kiat Sukses Panen Cabai Sepanjang Musim”. Jakarta: Agromedia Pustaka.

Peraturan Daerah Kabupaten Bantaeng Pasal 1 Nomor 20 Tahun 2013 Tentang Pemeliharaan Pertanian.

Putra, Made Caesar Surya Dwi, \& Wayan Ekawati. 2017. "Pengaruh Inovasi Produk, Harga, Citra Merek Dan Kualitas Pelayanan Terhadap Loyalitas Pelanggan Sepeda Motor Vespa”. Jurnal Ilmu Administrasi Negara. Diakses pada tanggal 4 April 13.24.

Sholeh, Muhammad. 2008. "Analisis Strategi Inovasi dan Dampaknya Terhadap Perusahaan”. Jurnal: Manajemen. Diakses pada tanggal 2 Mei, pukul 16.24.

Suwarsono, Muhammad. 2017. “Manajemen Strategik”. Yogyakarta: URP STIM YKPN Yogyakarta.

Syamsu, Ardhona, dkk. 2013. "Pengaruh Pemberian Dua Jenis Mulsa dan Tanpa Mulsa Terhadap Karakteristik Pertumbuhan dan Produksi Tanaman Cabai Merah". Jurnal Agroteknologi. Diakses pada tanggal 2 Desember, pukul 14.23.

Undang-Undang Republik Indonesia Nomor 39 Tahun 2014 Tentang Perkebunan. 